\title{
The model cyanobacteria Anabaena sp. PCC 7120 possess an intact but partially degenerated gene cluster encoding gas vesicles
}

\author{
Kun Cai ${ }^{1}$, Bo-Ying Xü ${ }^{2}$, Yong-Liang Jiang ${ }^{1}$, Ying Wang ${ }^{1}$, Yuxing Chen ${ }^{1}$, Cong-Zhao Zhou ${ }^{1+}$ and Qiong $\mathrm{Li}^{i^{* \dagger}}$ (D)
}

\begin{abstract}
Background: Bacterial gas vesicles, composed of two major gas vesicle proteins and filled with gas, are a unique class of intracellular bubble-like nanostructures. They provide buoyancy for cells, and thus play an essential role in the growth and survival of aquatic and soil microbes. Moreover, the gas vesicle could be applied to multimodal and noninvasive biological imaging as a potential nanoscale contrast agent. To date, cylinder-shaped gas vesicles have been found in several strains of cyanobacteria. However, whether the functional gas vesicles could be produced in the model filamentous cyanobacteria Anabaena sp. PCC 7120 remains controversial.

Results: In this study, we found that an intact gvp gene cluster indeed exists in the model filamentous cyanobacteria Anabaena sp. PCC 7120. Real-time PCR assays showed that the gvpA gene is constitutively transcribed in vivo, and its expression level is upregulated at low light intensity and/or high growth temperature. Functional expression of this intact gvp gene cluster enables the recombinant Escherichia coli to gain the capability of floatation in the liquid medium, thanks to the assembly of irregular gas vesicles. Furthermore, crystal structure of GvpF in combination with enzymatic activity assays of GvpN suggested that these two auxiliary proteins of gas vesicle are structurally and enzymatically conserved, respectively.
\end{abstract}

Conclusions: Our findings show that the laboratory strain of model filamentous cyanobacteria Anabaena sp. PCC 7120 possesses an intact but partially degenerated gas vesicle gene cluster, indicating that the natural isolate might be able to produce gas vesicles under some given environmental stimuli for better floatation.

Keywords: Gas vesicle, Cyanobacteria, Natural isolate, Heterologous expression, Crystal structure, ATPase activity

\footnotetext{
* Correspondence: liqiong@ustc.edu.cn

${ }^{+}$Cong-Zhao Zhou and Qiong Li contributed equally to this work.

'Hefei National Laboratory for Physical Sciences at the Microscale and School

of Life Sciences, University of Science and Technology of China, Hefei

230027, Anhui, China

Full list of author information is available at the end of the article
}

\section{$\triangle B M C$}

(c) The Author(s). 2020 Open Access This article is licensed under a Creative Commons Attribution 4.0 International License, which permits use, sharing, adaptation, distribution and reproduction in any medium or format, as long as you give appropriate credit to the original author(s) and the source, provide a link to the Creative Commons licence, and indicate if changes were made. The images or other third party material in this article are included in the article's Creative Commons licence, unless indicated otherwise in a credit line to the material. If material is not included in the article's Creative Commons licence and your intended use is not permitted by statutory regulation or exceeds the permitted use, you will need to obtain permission directly from the copyright holder. To view a copy of this licence, visit http://creativecommons.org/licenses/by/4.0/ The Creative Commons Public Domain Dedication waiver (http://creativecommons.org/publicdomain/zero/1.0/) applies to the data made available in this article, unless otherwise stated in a credit line to the data. 


\section{Background}

Gas vesicles (GVs), a unique class of intracellular bubble-like nanostructures, are found in many aquatic and soil microbes including halophilic archaea, photosynthetic bacteria, and heterotrophic bacteria [1]. Ambient gases could freely diffuse into and out of GVs, whereas water is impermeable, making the GV a gasfilled organelle [2, 3]. GVs could regulate the buoyancy of microbial cells, enabling the vertical floatation to an appropriate depth in aqueous environments for a better access of oxygen, light and even nutrients [4]. As an organelle composed of only proteins, GV adopts a spindle-shaped cylinder with conical end caps, usually of $45 \sim 250 \mathrm{~nm}$ in width and $100 \sim 2000 \mathrm{~nm}$ in length [5]. The unique physical properties allow GVs to serve as a potential nanoscale contrast agent for ultrasound and magnetic resonance imaging, which yields multimodal and noninvasive biological imaging with high spatial and temporal resolution [6].

As previously reported, formation of GVs is related to a conserved cluster of $8 \sim 14$ genes (termed gas vesicle protein gene cluster, or gvp gene cluster for short), encoding two major structural proteins and several essential minor components that might putatively function as chaperones, nucleators and regulators $[2,5,7]$. The primary structural protein GvpA and the external scaffold protein GvpC constitute the 2-nm-thick outer amphiphilic shell of the GV $[2,5,8]$. GvpA, a 7.5-kDa highly conserved and hydrophobic protein, assembles into tandem arrays that form 4.6-nm-wide characteristic ribs running nearly perpendicular to the long axis of the GV $[9,10]$. Notably, most cyanobacteria possess multiple copies of $g v p A$ gene, for example, two in Calothrix sp. [11], three in Microcystis aeruginosa [12] and five in Anabaena flos-aquae [13]. In contrast, GvpC is a lessabundant, not conserved, and highly hydrophilic protein [14]. GvpC usually contains a number of conserved 33residue repeating motif (33RR), and functions to connect GvpA molecules in the same and/or adjacent ribs to strengthen and stabilize the shell of GV [15]. In vitro experiments demonstrated that removal of GvpC leads to a three-fold decrease of the critical collapse pressure of GVs, whereas addition of GvpC helps GVs to restore normal strength [16, 17]. In addition, GvpF is reported to be a structural protein localized at the inner surface of GVs [18].

To date, a series of cyanobacteria have been found to produce GVs, such as A. flos-aquae, Calothrix sp. PCC 7601, M. aeruginosa PCC 7806, Oscillatoria sp. 6412, Pseudanabaena, Nostoc sp. 6705 [12, 19]. Notably, filamentous cyanobacteria Calothrix and Nostoc can differentiate hormogonia upon environmental stimuli, the process of which is characterized by the formation of GVs [2, 20]. Despite the laboratory strain of model filamentous cyanobacteria Anabaena sp. PCC 7120 fails in differentiating hormogonia $[19,21]$, it remains unknown whether the natural isolate could differentiate hormogonia and produce GVs. Here we found that Anabaena sp. PCC 7120 possesses an intact gvp gene cluster, which shares an organization similar to that of previously identified GVforming cyanobacteria. The results of real-time PCR showed that $g v p A$ is constitutively transcribed in vivo, and its expression level could be augmented at an altered light intensity and growth temperature. The complete gvp gene cluster could be heterologously expressed and assembled into irregular GVs in Escherichia coli. Moreover, structural combined with enzymatic investigations suggested that GvpF and GvpN are structurally and enzymatically conserved, respectively. These findings indicated that the natural isolate of Anabaena sp. PCC 7120 is most likely able to produce GVs under some given environmental stimuli.

\section{Results \\ Organization and conservation of the gvp genes in Anabaena sp. PCC 7120}

The entire genomic sequence of the model filamentous nitrogen-fixing cyanobacteria Anabaena sp. PCC 7120 was reported in 2001, which consists of a single circular genome of $6,413,771 \mathrm{bp}$ and six plasmids [22]. Eight out of the 5368 putative open reading frames in the genome were annotated as $g v p$ genes: $g \nu p A, g v p B, g \nu p C, g v p N$, $g v p J, g v p K, g v p F$ and $g v p G$, without annotations of $g v p V$ and $g v p W$ compared to some other $g v p$ gene clusters. Using BlastP program, we found that the proteins encoded by alr 2246 and alr2245, two genes at the downstream of $g \nu p G$, share a sequence similarity of $62 \%$ and $65 \%$ to GvpV and GvpW of M. aeruginosa PCC 7806, respectively. Thus we assigned alr2246 and alr2245 to $g \nu p V$ and $g v p W$, respectively (Fig. 1). It suggested that Anabaena sp. PCC 7120 possesses an intact gvp gene cluster, which shares a gene organization similar to that in the previously reported GV-forming cyanobacteria, such as A. flos-aquae and M. aeruginosa PCC 7806. Notably, most of the gvp genes in GV-forming Haloarchaea and other bacteria are highly conserved [5], despite the gene organizations vary a lot (Fig. 1).

Multiple-sequence alignment showed that $g v p B$ is nearly identical to $g \nu p A$ in the $g \nu p$ gene cluster of $A n a$ baena sp. PCC 7120, suggesting that $g v p B$ is an isoform of $g v p A$. Accordingly, $g v p A$ and $g v p B$ should be reannotated to $g v p A 1$ and $g v p A 2$, respectively (Fig. 1). Moreover, GvpA of Anabaena sp. PCC 7120 shares a sequence similarity to those of other cyanobacterial strains up to $90 \%$ (Fig. 2a), indicating that the primary structural protein GvpA exhibits a rarely high conservativity in cyanobacteria. Further sequence analysis revealed that the external scaffold protein GvpC of Anabaena sp. PCC 7120 contains only three conserved 33RRs (Fig. 2b), 
Anabaena sp. PCC 7120

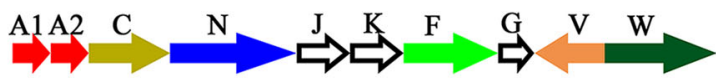

Anabaena flos-aquae CCAP 1403/13F

Microcystis aeruginosa PCC 7806

Bacillus megaterium DSM 319

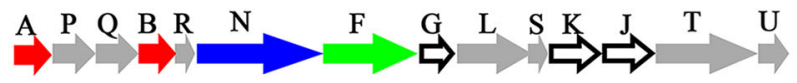

Serratia sp. ATCC 39006

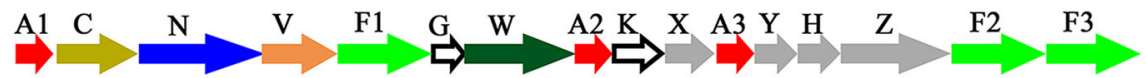

Halobacteruim salinarum PHH1

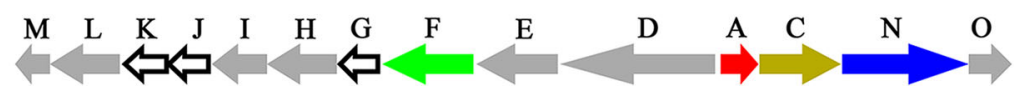

Fig. 1 Organizations of the grp gene cluster from different species of bacteria. Each alphabet above the arrow represents a grp gene.

Transcription direction of each gene is indicated by the arrow. The gvp genes absent in Anabaena sp. PCC 7120 are shown as grey arrows

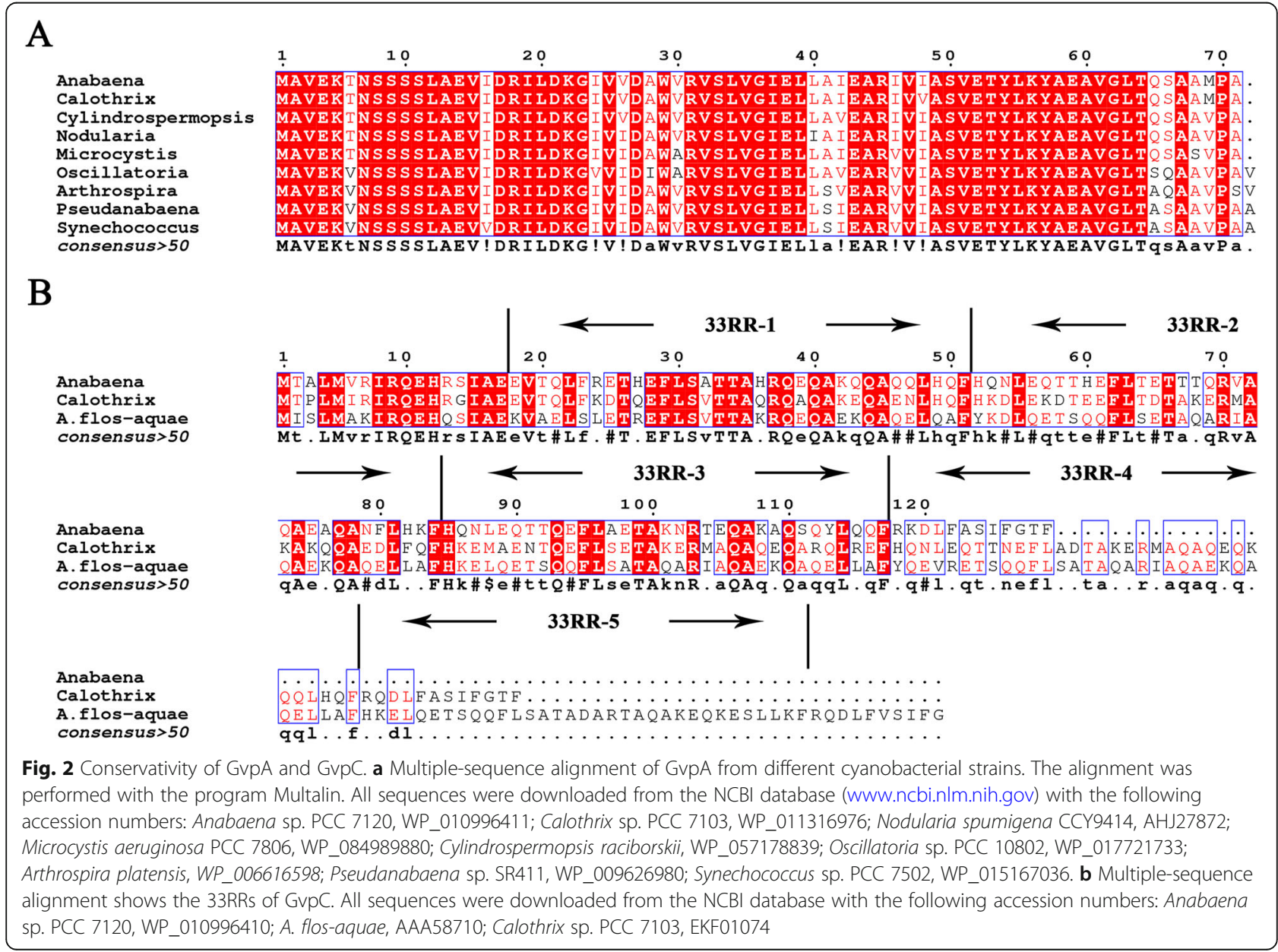


which probably result in GVs of smaller diameter. In fact, a previous report revealed that A. flos-aquae GVs with a GvpC of five 33RRs have a larger diameter compared to those of Calothrix sp. PCC 7601 with a GvpC of four 33RRs [23].

\section{The gvpA gene is upregulated at low light intensity and} high temperature

Considering that the transcription of $g v p$ genes is the prerequisite of GV formation, we investigated whether the gvpA gene, encoding the major structural component of GV, could be transcribed in vivo. The total RNA was extracted from Anabaena sp. PCC 7120 cells grown at a light intensity of $2000 \mathrm{lux}$ at $28^{\circ} \mathrm{C}$, and applied to realtime PCR assays. The results showed that an expected fragment of $g v p A$ could be detected (Fig. 3), suggesting that the $g v p A$ gene is constitutively transcribed in Anabaena sp. PCC 7120 under normal laboratory growth condition.

Afterwards, we shifted Anabaena sp. PCC 7120 cells to various external stimuli and detected the expression profiles of $g v p A$ gene. The expression level of $g v p A$ in Anabaena sp. PCC 7120 upon a single stimulus of low light intensity at 200 lux or high temperature at $38^{\circ} \mathrm{C}$ were elevated to 6 and 11 folds, respectively (Fig. 3), compared to the constitutive expression level. Moreover, when Anabaena sp. PCC 7120 cells were grown under the condition of double stimuli of both low light intensity and high temperature, the expression level of $g v p A$

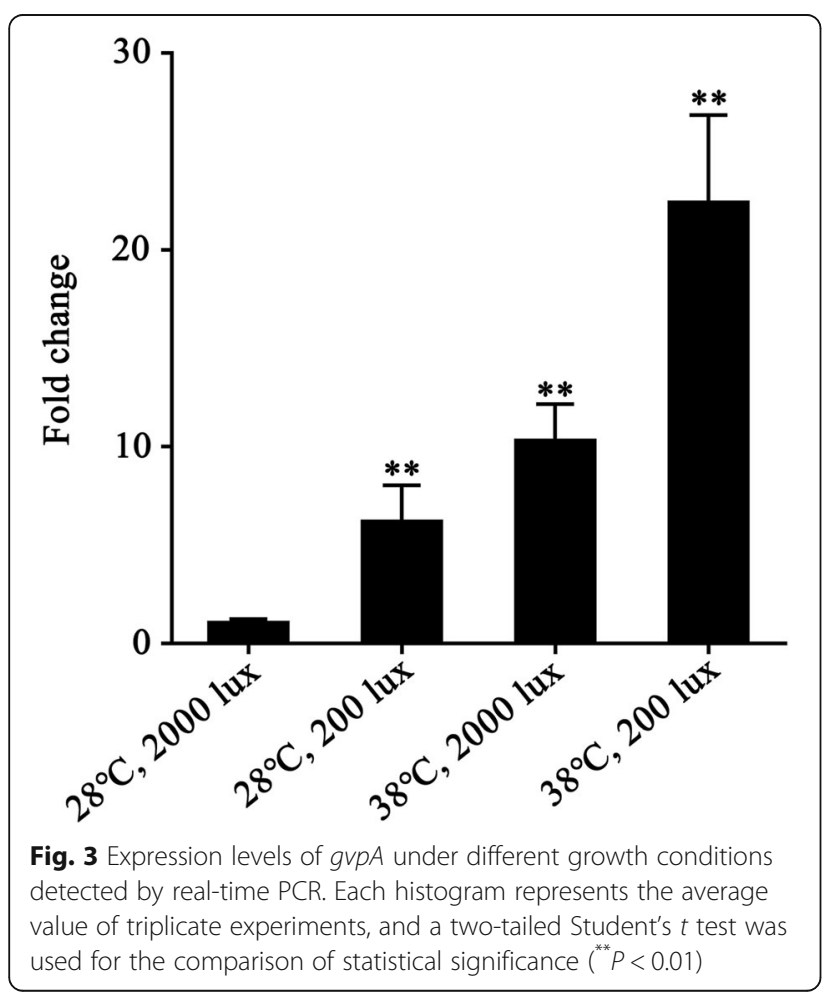

was upregulated approximately 23 folds (Fig. 3). Considering that GvpA is the primary structural component of GV, we speculated that prototype GVs could be produced in Anabaena sp. PCC 7120 at some given conditions. However, we failed in observing the floatation of Anabaena sp. PCC 7120 cells in response to the above double stimuli. It implied that mature and functional GVs do not exist in the laboratory strain of Anabaena sp. PCC 7120, in consistence with its incapability of differentiating hormogonia.

\section{Expression of the gvp gene cluster of Anabaena sp. PCC 7120 in E. coli}

The gvp genes of Anabaena sp. PCC 7120 were constructed in the expression vectors and then transformed to $E$. coli cells. Interestingly, we observed that the $E$. coli cells transformed with the recombinant gvp plasmids exhibit a buoyancy phenotype, whereas the cells carrying the control vectors sink to the bottom of the tube (Fig. 4a). Then, the turbidity measurements showed that the upper fraction of the culture medium of the experimental group has an absorbance of 0.57 at $600 \mathrm{~nm}$, compared to 0.02 of the control. The results suggested that GVs might be produced in the recombinant E. coli cells that harbor the gvp gene cluster of Anabaena sp. PCC 7120 .

Afterwards, the recombinant GVs were purified from E. coli cells and applied to transmission electron microscopy, following a previously reported protocol [18]. The image displayed a large number of round and oval bubble-like structures (Fig. 4b), similar to those irregular GVs via expressing Bacillus megaterium gvp gene cluster in $E$. coli [24]. In contrast, similar bubble-like structures were absent from the $E$. coli cells that expressing the control vectors (Fig. 4b). Western blot assays further showed that the purified GVs possess enriched Histagged GvpA proteins (Fig. 4c). Altogether, transformation of the gvp gene cluster of Anabaena sp. PCC 7120 enabled $E$. coli to display a buoyancy phenotype, because of the assembly of GVs, indicating that Anabaena sp. PCC 7120 possesses an intact $g v p$ gene cluster capable of heterogeneously producing irregular but functional GVs.

\section{The crystal structure of GvpF}

To further investigate the putative GVs of Anabaena sp. PCC 7120 from the structural point of view, all Gvp proteins, except for GvpA and $\mathrm{GvpC}$, were successfully overexpressed, purified and applied to crystal screening; however, only the crystal structure of GvpF was eventually solved at $2.55 \AA$ resolution in the space group $C 222_{1}$ (Table 1). Anabaena sp. PCC $7120 \mathrm{GvpF}$ is composed of two structurally separated domains, both of which display a fold in $\alpha+\beta$ class, followed by a C-terminal tail 


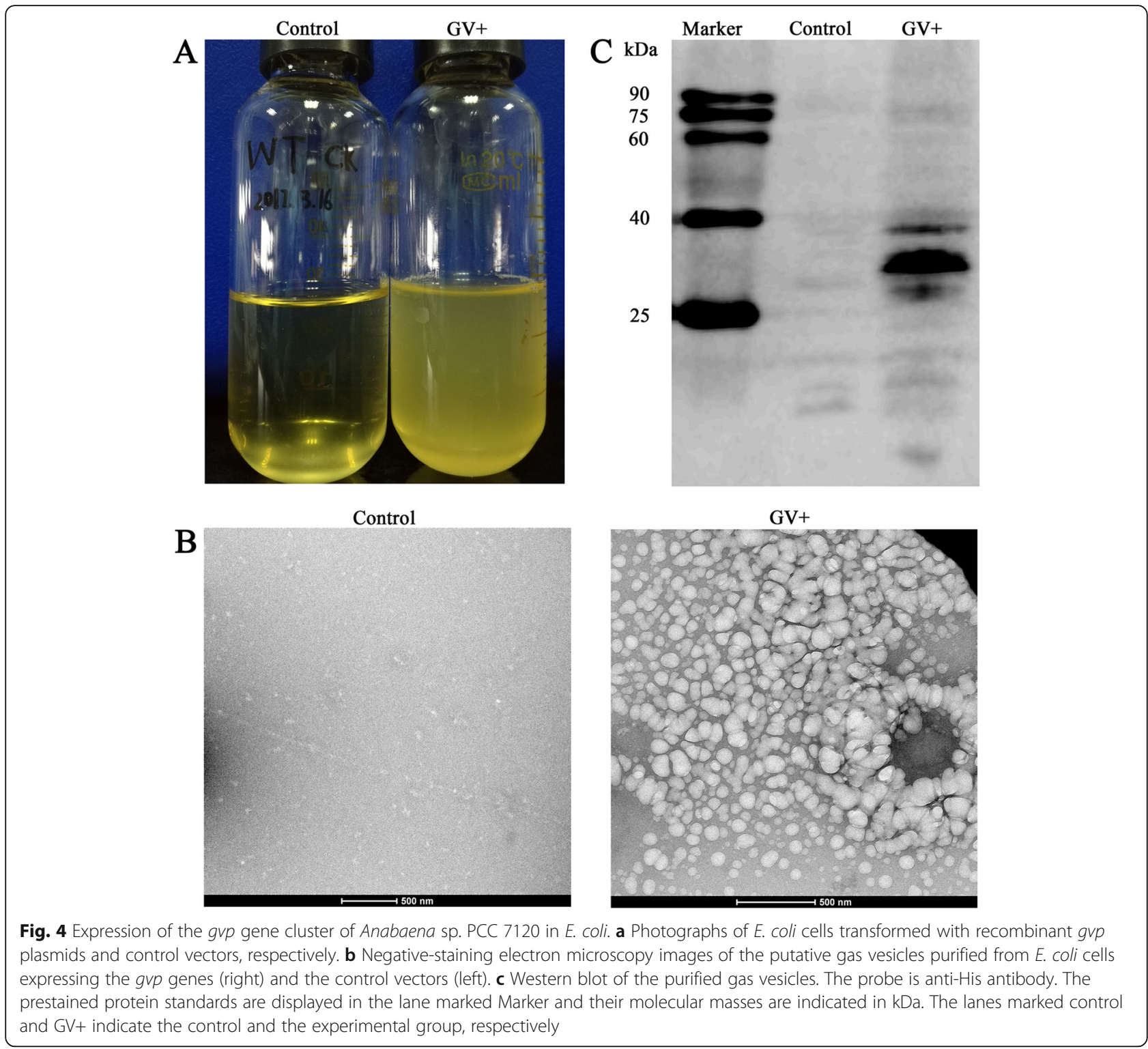

inserted into the middle area of the two domains (Fig. 5a). Further structural analysis showed that the Ndomain of GvpF displays an architecture in which a sixstranded $\beta$-sheet $(\beta 1-\beta 6)$ is sandwiched by two $\alpha$-helices $(\alpha 1-\alpha 2)$ and the helix $\eta 1$, whereas the $C$-domain adopts a modified ferredoxin fold owing to an extension region consisting of three consecutive helices ( $\alpha 4, \alpha 5$ and the $\mathrm{N}$-terminal segment of $\alpha 6$ ) (Fig. 5a). Moreover, the additional C-terminal tail provides an interface for the $\mathrm{N}$ domain and $\mathrm{C}$-domain to pack against each other, resulting in the structural stability and correct folding of GvpF (Fig. 5a).

DALI search [25] revealed that Anabaena sp. PCC $7120 \mathrm{GvpF}$ shares a high structural homology to the previously reported GvpF of $M$. aeruginosa PCC 7806 (PDB code: 4 QSG, Z score 27.5 , sequence identity $67 \%$ ), with a root-mean-square deviation of $1.8 \AA$ over $238 \mathrm{C \alpha}$ atoms. Superposition of the two structures showed a very similar structure, except that GvpF of Anabaena sp. PCC 7120 possesses a shorter helix $\alpha 5$ in the $\mathrm{C}$-domain (Fig. $5 \mathrm{~b})$. Besides, structure-based multiple-sequence alignment revealed that GvpF proteins are highly conserved among diverse species of cyanobacteria (Fig. 5c). It indicated that Anabaena sp. PCC $7120 \mathrm{GvpF}$ might also function as a structural protein involved in forming GVs as that of M. aeruginosa PCC 7806 [18].

\section{GvpN is an active ATPase}

Sequence analysis against the Pfam database [26] showed that Anabaena sp. PCC 7120 GvpN contains an ATPases Associated with various cellular Activities (AAA) domain at the $\mathrm{N}$-terminus, which was previously 
Table 1 Crystal parameters, data collection, and structure refinement

\begin{tabular}{|c|c|}
\hline & GvpF \\
\hline \multicolumn{2}{|l|}{ Data collection } \\
\hline Space group & $\mathrm{C} 222_{1}$ \\
\hline \multicolumn{2}{|l|}{ Unit cell parameters } \\
\hline$a, b, c(\AA)$ & $96.40,147.09,106.58$ \\
\hline$a, \beta, \gamma\left({ }^{\circ}\right)$ & $90.00,90.00,90.00$ \\
\hline Resolution range $(\AA)$ & $50.00-2.55(2.62-2.55)^{a}$ \\
\hline Unique reflections & $24,900(2,440)$ \\
\hline Completeness (\%) & $99.9(100)$ \\
\hline$<\mid / \sigma(I)>$ & $16.3(2.9)$ \\
\hline$R_{\text {merge }}{ }^{b}(\%)$ & $10.6(69.1)$ \\
\hline Average redundancy & $10.9(10.9)$ \\
\hline \multicolumn{2}{|l|}{ Structure refinement } \\
\hline Resolution range $(\AA)$ & $44.46-2.55$ \\
\hline$R_{\text {factor }}{ }^{c} / R_{\text {free }}{ }^{d}(\%)$ & $19.57 / 25.61$ \\
\hline Number of protein atoms & 3,962 \\
\hline Number of water atoms & 28 \\
\hline RMSD ${ }^{e}$ bond lengths $(\AA)$ & 0.015 \\
\hline RMSD bond angles $\left({ }^{\circ}\right)$ & 1.709 \\
\hline Mean B factors $\left(\AA^{2}\right)$ & 53.189 \\
\hline \multicolumn{2}{|c|}{ Ramachandran plot (residues, \%) ${ }^{f}$} \\
\hline Most favored & 95.80 \\
\hline Allowed & 4.00 \\
\hline Outliers & 0.20 \\
\hline Protein Data Bank entry & $6 L 5 D$ \\
\hline
\end{tabular}

${ }^{a}$ Highest resolution shell is shown in parenthesis. $R_{\text {sym }}=\Sigma_{h} \Sigma_{i}\left|l_{h, i}-I_{h}\right| / \Sigma_{h} \Sigma_{i} l_{h, i}$ where $I_{h}$ is the mean intensity of the $i$ observations of symmetry related reflections of $h . \mathrm{R}=\Sigma\left|\mathrm{F}_{\text {obs }}-\mathrm{F}_{\text {calc }}\right| / \Sigma \mathrm{F}_{\text {obs }}$, where $F_{\text {obs }}=F_{p}$, and $F_{\text {calc }}$ is the calculated protein structure factor from the atomic model. RMSD in bond lengths and angles are the deviations from ideal values

classified in the AAA+ protein superfamily of the ringshaped P-loop NTPases [27]. Therefore, the recombinant GvpN of Anabaena sp. PCC 7120 was overexpressed in E. coli and purified (Fig. 6a), which was applied to the ATPase activity assays. Upon the addition of recombinant GvpN, the substrate ATP was gradually hydrolyzed over time (Fig. 6b). Upon the increase of GvpN added to the reaction, the ATP was hydrolyzed at a higher rate (Fig. 6b), suggesting that GvpN indeed possesses the ATPase activity. Using the Hanes-Woolf plot method (Fig. 6c), we determined the Michaelis-Menten parameters of GvpN towards ATP at a $K_{m}$ of $3.9 \pm 1.5 \mu \mathrm{M}, k_{\text {cat }}$ of $35 \pm 2 \mathrm{~s}^{-1}$ and $k_{\text {cat }} / K_{m}$ of $8.97 \mathrm{~s}^{-1} \mu \mathrm{M}^{-1}$. Moreover, multiple-sequence alignment showed that the AAA domain of GvpN is highly conserved among different cyanobacterial species (Fig. 6d), indicating that the ATPase activity is a common feature of GvpN. In fact, a previous report showed that deletion of GvpN in
Serratia sp. ATCC 39006 led to small bicone-shaped GVs and lack of cell buoyancy [28]. All together, it suggested that Anabaena sp. PCC 7120 possesses an enzymatically active GvpN, which might be necessary for the formation of mature GVs.

\section{Discussion}

GVs play an essential role in the survival of prokaryotic species, and thus should be assembled or disassembled properly at the right time in response to diverse external stimuli. Actually, the formation of GVs or the expression of genes encoding Gvp proteins are affected by various environmental stimuli, such as temperature, light intensity, oxygen supply, $\mathrm{pH}$ and salinity, cell density and carbon source $[5,29-32]$. For the cyanobacteria A. flosaquae, Calothrix sp. PCC 7601 and Microcystis sp. BC $84 / 1$, low light intensity could induce more GVs in order to enable the cells to move towards the surface of the aqueous habitat [5]. Mlouka and colleagues found that lack of nutrition, especially $\mathrm{CO}_{2}$ and light irradiance, leads to an augmented production of GVs in M. aeruginosa [12]. Moreover, for enterobacteria Serratia sp. ATCC39006, the formation of GVs depends on cell density under the control of quorum-sensing signals, and is responsive to oxygen shortage, resulting in facilitating the buoyancy of cells [28, 33]. In addition, for haloarchaea, two regulatory proteins $\mathrm{GvpD}$ and GvpE were shown to be involved in regulating the expression of $g v p$ genes at both transcriptional and translational level [34]. Altogether, the formation of GVs is necessary for some bacteria in response to various environmental conditions.

The model filamentous and heterocyst-forming cyanobacteria Anabaena sp. PCC 7120 were isolated from the Lake Michigan in the late 1960s [22]. Theoretically, the environmental stimuli mentioned above should probably induce the formation of GV in Anabaena sp. PCC 7120, which possesses the $g v p$ gene cluster. However, no one has observed GVs in the past 50 years of studying the physiology of this model organism. In this study, we found that Anabaena sp. PCC 7120 has an intact gvp gene cluster similar to those GV-forming cyanobacterial strains (Fig. 1). In fact, $A$. flos-aquae and $M$. aeruginosa PCC 7806 were proved to be able to produce cylindershaped GVs, the formation of which was regulated by light intensity $[2,12]$. It is most likely that Anabaena sp. PCC 7120 is also capable of forming GVs under some given environmental stimuli. Indeed, the primary structural gene gvpA of Anabaena sp. PCC 7120 is constitutively transcribed, and could be upregulated at low light intensity and high temperature (Fig. 3). Heterologous expression of the intact Anabaena sp. PCC 7120 gvp gene cluster enabled $E$. coli cells to gain the capacity of floatation, thanks to the formation of irregular GVs (Fig. 4). 


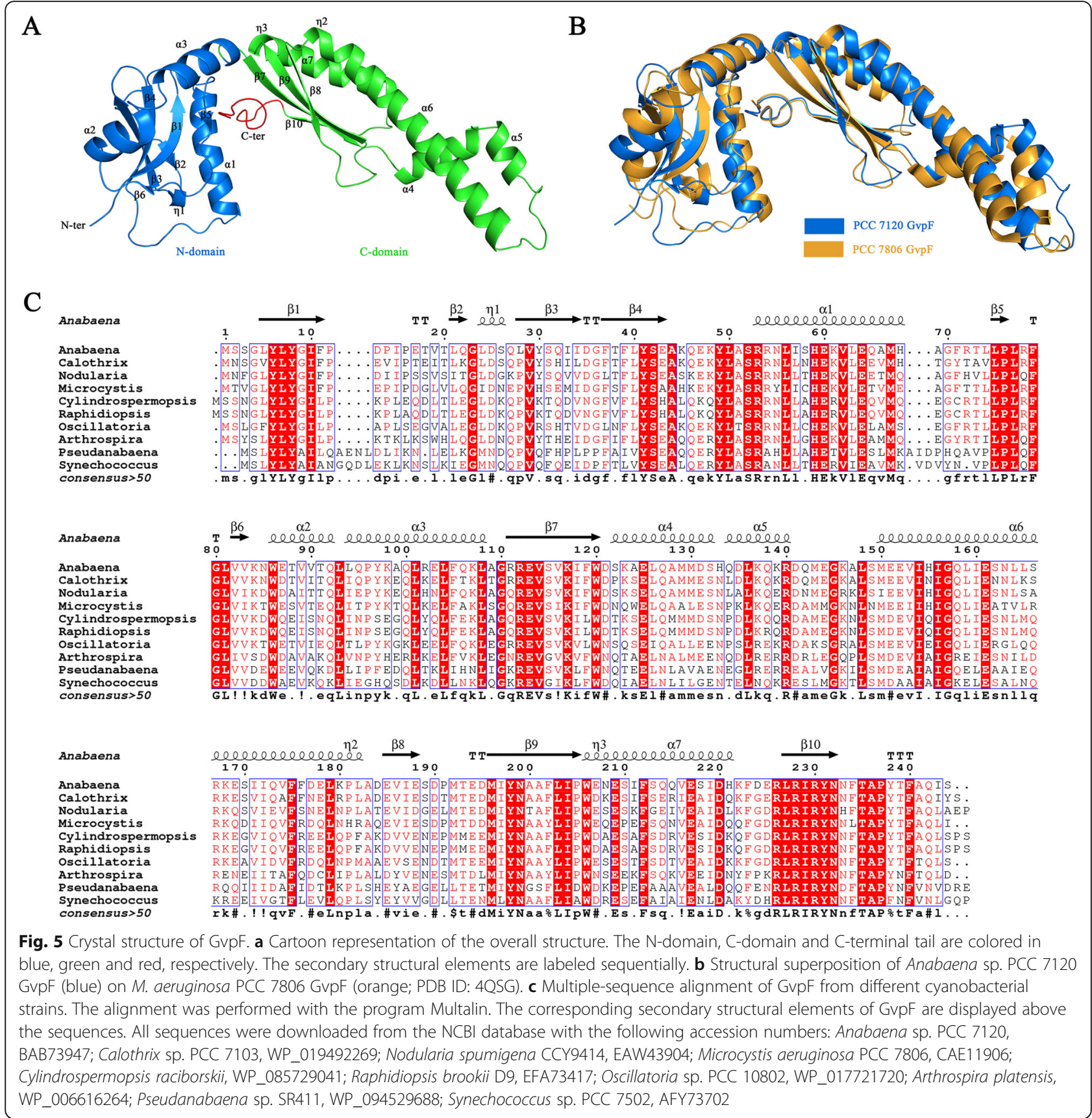

However, we failed in either setting up a reproducible procedure to enable the floatation of Anabaena sp. PCC 7120 , or seeing GVs inside the cells, or purifying GVs from this laboratory strain, after extensive trials of various stimuli and combinations. It indicated that the gvp gene cluster of Anabaena sp. PCC 7120 was partially degenerated in the 50-year laboratory culture.

Notably, formation of GVs is a key feature accompanied with the differentiation of hormogonia, which has already been proved in filamentous cyanobacteria Calothrix and Nostoc $[2,20]$. Recently, Gonzalez and colleagues reported that hormogonia differentiation is regulated by a hierarchal sigma factor cascade in the filamentous cyanobacteria Nostoc punctiforme, which retain the developmental complexity of natural isolates [21]. In detail, the sigma factor sigJ activates the expression of both $\operatorname{sig} C$ and $\operatorname{sig} F$ genes, as well as other hormogonium-specific genes; meanwhile, sigJ controls the transcription of $g v p A$ gene via binding at the -10 region, which is a consensus sigJ-dependent promoter (designated as J-Box, GGGaAtacT) [21]. However, we found that the highly conserved GGG stretch of J-Box was mutated to AGC at the upstream promoter region of 


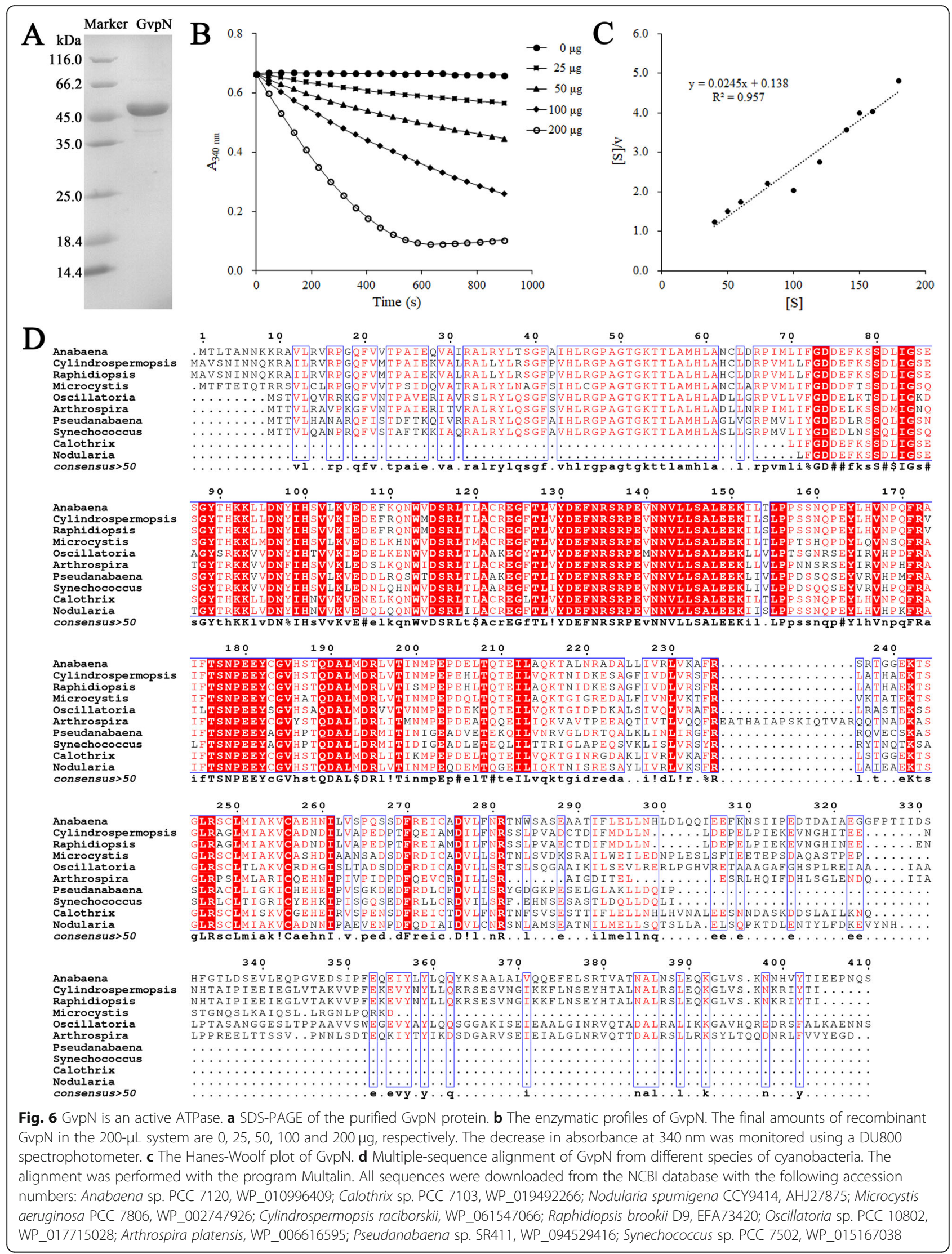


$g v p A$ in the laboratory strain of Anabaena sp. PCC 7120, which might result in the altered binding affinity towards sigJ, and eventually the failure of producing functional GVs. It indicated that the natural isolate of Anabaena sp. PCC 7120, without the mutations at the regulatory region of $g v p$ gene cluster, might be capable of differentiating hormogonia and producing GVs for better floatation in response to some given environmental stimuli. More investigations including comparative genomics analyses might help us to clearly elucidate which mutations in the present laboratory strain of Anabaena PCC 7120 lead to the loss of function.

\section{Conclusions}

In this study we demonstrated that the laboratory model filamentous cyanobacterium Anabaena sp. PCC 7120 indeed possesses an intact but partially degenerated gene cluster encoding gas vesicles, which gives us the hint that its natural isolate was most likely able to produce GVs under some given environmental stimuli. Owing to the fast growth and non-toxicity of the model strain sp. PCC 7120, investigations that enable the large production of GVs in this strain will benefit the potential application of GVs in biological imaging.

\section{Methods}

\section{RNA extraction and real-time PCR}

The Anabaena sp. PCC 7120 cells were grown at $28^{\circ} \mathrm{C}$ under a light intensity of 2000 lux (supplied from top) with a $12 / 12$ photoperiod in BG-11 medium to an $\mathrm{OD}_{730 \mathrm{~nm}}$ of 0.8 , and then induced with 200 lux light intensity, $38^{\circ} \mathrm{C}$ and both for $24 \mathrm{~h}$, respectively. The stressors were selected according to a previous report summarizing the environmental conditions that could induce the formation of gas vesicles [5]. The cells were harvested by centrifugation and washed twice with the PBS buffer. The total RNA was extracted using the RNeasy Mini Kit (Qiagen, Hilden, Germany) according to the manufacturer's protocol. The residual genomic DNA was removed by RNase-free DNase (Takara, Shiga, Japan) at $37^{\circ} \mathrm{C}$ for $2 \mathrm{~h}$. PCR assays were conducted to confirm the absence of genomic DNA contamination. The RNA quality was checked by agarose gel electrophoresis. The cDNA synthesis was carried out by reverse transcription using the PrimeScript ${ }^{\text {ti }}$ RT reagent Kit (Takara, Shiga, Japan).

For real-time PCR, amplification was performed using the FastStart universal SYBR Green Master (Roche, Basel, Switzerland) with the StepOne ${ }^{\mathrm{Tm}}$ Real-Time PCR System (Applied Biosystems, Carlsbad, USA). The primers for $r n p B$ are 5'-GCGATTATCTATCTGGGA CG and 5'-CAACTCTTGGTAAGGGTGC, whereas those for $g v p A$ are 5'-TGGCAGAAGTTATTGACC and 5'-GAGAAACACGTACCCAAG. Notably, the $r n p B$ gene encoding RNaseP subunit B was used as the internal reference gene according to previous real-time PCR experiments concerning cyanobacteria [35]. The PCR conditions were as follows: 1 cycle at $95^{\circ} \mathrm{C}$ for 10 min, 40 cycles at $95^{\circ} \mathrm{C}$ for $15 \mathrm{~s}, 60^{\circ} \mathrm{C}$ for $60 \mathrm{~s}$, and $72^{\circ} \mathrm{C}$ for $20 \mathrm{~s}$; then the melting curve stage was performed rising from $60^{\circ} \mathrm{C}$ to $95^{\circ} \mathrm{C}$ by every $0.3^{\circ} \mathrm{C}$. The transcription ratios of $g \nu p A$ to $\operatorname{rnpB}$ were calculated using the relative quantification analysis module of $2^{-\Delta \Delta C t}$ method based on $C t$ values [36]. All real-time PCR experiments were performed in triplicate.

\section{Buoyancy tests}

The $g v p A B C$, gvpNJKFG and $g v p V W$ genes of Anabaena sp. PCC 7120 were amplified and cloned into pET-Duet, pET-28a and pCDFDuet-1 vectors (with different antibiotic markers), respectively. Notably, a His-tag was fused to the N-terminus of GvpA for detecting the expression of the gene cluster. Next, the three $g v p$ recombinant plasmids were co-overexpressed in E. coli BL21 (DE3) strain. Cells were grown in liquid LB broth, induced with isopropyl $\beta$-D-1-thiogalactopyranoside (IPTG) for $4 \mathrm{~h}$ at $37^{\circ} \mathrm{C}$, and resuspended in 35-mm-diameter test tubes. Then, the tubes were undisturbed at room temperature for about 24 $\mathrm{h}$, at which time the cell buoyancy was determined by the turbidity of the upper fraction of the culture medium. The cells transformed with the empty vectors without gvp gene cluster were used as the control.

\section{GV isolation, electron microscopy and western blot}

According to a previously described protocol [18], GVs were purified from $E$. coli cells co-overexpressing the three recombinant plasmids that cover the complete gvp gene cluster. Carbon-coated copper grids (300-mesh) were immersed in the purified GVs for $1 \mathrm{~min}$ and excess liquid was removed with filter paper. GVs were negatively stained with $2 \%(\mathrm{w} / \mathrm{v})$ uranyl acetate and then examined with a Tecnai $G^{2}$ transmission electron microscopy (FEI, USA) running at $120 \mathrm{kV}$ voltage. Images were taken using a CCD camera attached to the microscopy. The purified GVs were mixed with an equal volume of $2 \times$ sample-loading buffer (100 mM Tris-HCl, pH 6.8, 4\% SDS, 20\% glycerol, $2 \% \quad \beta$-mercaptoethanol, $0.2 \%$ bromophenol blue), boiled for $10 \mathrm{~min}$, and then applied to western blot using anti-His polyclonal antibodies.

\section{Cloning, expression and purification of GvpF and GvpN}

The coding region of $g \nu p F$ was amplified from the genomic DNA of Anabaena sp. PCC 7120, and cloned into a modified pET-29a vector with a C-terminal $6 \times$ Histag. The E. coli BL21 (DE3) strain was used for the overexpression of recombinant protein. The transformed cells were grown at $37^{\circ} \mathrm{C}$ until $\mathrm{OD}_{600 \mathrm{~nm}}$ reached 0.8 and then induced with $0.2 \mathrm{mM}$ IPTG for another $20 \mathrm{~h}$ at 
$16^{\circ} \mathrm{C}$. Cells were harvested by centrifugation $(6000 \times \mathrm{g}$, $\left.4{ }^{\circ} \mathrm{C}, 10 \mathrm{~min}\right)$ and resuspended in the lysis buffer $(20 \mathrm{mM}$ Tris- $\mathrm{HCl}, \mathrm{pH} 7.5,100 \mathrm{mM} \mathrm{NaCl}$ ). After $10 \mathrm{~min}$ of sonication on ice and $30 \mathrm{~min}$ of centrifugation at $12,000 \times \mathrm{g}$, the supernatant was loaded onto a Ni-NTA column (GE Healthcare, Chicago, USA) equilibrated with the binding buffer, the same as the lysis buffer. The target protein was eluted with $300 \mathrm{mM}$ imidazole and further applied to a Superdex 200 column (GE Healthcare, Chicago, USA) pre-equilibrated with the binding buffer. Fractions containing the target protein were collected and concentrated to $10 \mathrm{mg} / \mathrm{mL}$ for crystallization.

GvpN was expressed and purified in the same manner as GvpF. Samples for ATPase activity assays were collected at the highest peak fractions without concentration and stored at $-80^{\circ} \mathrm{C}$ with $50 \%$ glycerol.

\section{Crystallization, data collection and structure determination}

Crystals of GvpF were grown at $16^{\circ} \mathrm{C}$ using the hanging drop vapor diffusion method, with a drop of $1 \mu \mathrm{L}$ protein solution mixed with an equal volume of the reservoir solution. Crystals were obtained against the reservoir solution of $20 \%(\mathrm{w} / \mathrm{v})$ polyethylene glycol $4000,0.2 \mathrm{M} \mathrm{NaCl}$, and $0.1 \mathrm{M}$ Tris- $\mathrm{HCl}, \mathrm{pH}$ 8.0. Then, they were pooled and flash cooled with liquid nitrogen after transferring to cryoprotectant (reservoir solution supplemented with $30 \%$ sucrose). The X-ray diffraction data were collected at $100 \mathrm{~K}$ using beamline BL17U with an EIGER X $16 \mathrm{M}$ detector at the Shanghai Synchrotron Radiation Facility.

The diffraction data were indexed, integrated and scaled with HKL-2000 to the highest resolution of 2.55 $\AA$. The structure of $M$. aeruginosa PCC 7806 GvpF (PDB code: 4QSG) was used as the search model to determine the structure of Anabaena sp. PCC $7120 \mathrm{GvpF}$ by molecular replacement using the Molrep program [37] in the CCP4i program suite [38]. Further refinement was performed by programs REFMAC5 [39] and COOT [40]. The final model was evaluated with MolProbity [41]. Crystallographic parameters and data-collection statistics are listed in Table 1. All structure figures were prepared with PyMOL (https://pymol.org).

\section{ATPase activity assays of GvpN}

The ATPase activity of GvpN was measured using an ATP/NADH coupled assay [42], in which the decrease of NADH is proportional to the rate of steady-state ATP hydrolysis. The reaction mixture contains $50 \mathrm{mM}$ Tris$\mathrm{HCl}, \mathrm{pH}$ 8.0, $20 \mathrm{mM} \mathrm{KCl}, 5 \mathrm{mM} \mathrm{MgCl} 2,2.5 \mathrm{mM}$ ATP, 1 $\mathrm{mM}$ phosphoenolpyruvate, $0.1 \mathrm{mM} \mathrm{NADH}, 12 \mathrm{U} / \mathrm{mL}$ pyruvate kinase (Sigma, Saint Louis, USA) and $12 \mathrm{U} / \mathrm{mL}$ lactate dehydrogenase (Sigma, Saint Louis, USA). The reaction was initiated by the addition of recombinant GvpN, final amounts of which in a $200-\mu \mathrm{L}$ system are 0 ,
25, 50, 100 and $200 \mu \mathrm{g}$, respectively. Using a DU800 spectrophotometer (Beckman Coulter, Fullerton, USA), the decrease in absorbance at $340 \mathrm{~nm}$ was monitored at $25^{\circ} \mathrm{C}$ at $45 \mathrm{~s}$ intervals for $15 \mathrm{~min}$. Michaelis-Menten parameters of GvpN were calculated from the data at the concentration of NADH varying from 40 to $200 \mu \mathrm{M}$ and in the presence of $50 \mu \mathrm{g}$ GvpN using the Hanes-Woolf plot method.

\begin{abstract}
Abbreviations
GV: Gas vesicle; gvp gene cluster: Gas vesicle protein gene cluster; 33RR: 33Residue repeating motif; IPTG: isopropyl $\beta$-D-1-thiogalactopyranoside; AAA protein: ATPases Associated with various cellular Activities protein.
\end{abstract}

\section{Acknowledgements}

We appreciate the assistance of the staff at the Shanghai Synchrotron Radiation Facility (SSRF) and the Core Facility Center for Life Sciences at University of Science and Technology of China.

\section{Authors' contributions}

CZZ and QL conceived and designed the experiments; KC and YW performed the experiments; $K C$ and $Y L J$ solved and refined the structure; $K C$ and BYX performed the ATPase activity assays; KC, YC, CZZ and QL analyzed the data; CZZ and QL wrote and revised the manuscript. All authors read and approved the final manuscript.

\section{Funding}

This work is supported by the National Natural Science Foundation of China (Grant No. 31500602), the Ministry of Science and Technology of China (Grant No. 2016YFA0400900), National Synchrotron Radiation Laboratory (Grant No. UN2018LHJJ) and Chongqing Research Program of Basic Research and Frontier Technology (Grant No. cstc2015jcyjBX0142). The funding bodies had no role in study design, data collection, analysis and interpretation, and in writing of the manuscript.

\section{Availability of data and materials}

Structural coordinate of Anabaena sp. PCC $7120 \mathrm{GvpF}$ has been deposited in the Protein Data Bank (https://www.rcsb.org/) under the accession number of 6L5D. The datasets used and/or analysed during the current study available from the corresponding author on reasonable request.

Ethics approval and consent to participate Not applicable.

\section{Consent for publication}

Not applicable.

\section{Competing interests}

The authors declare that they have no competing interests.

\section{Author details}

${ }^{1}$ Hefei National Laboratory for Physical Sciences at the Microscale and School of Life Sciences, University of Science and Technology of China, Hefei 230027, Anhui, China. ${ }^{2}$ College of Life Sciences, Chongqing Normal University, Chongqing 401331, China.

Received: 18 December 2019 Accepted: 27 April 2020

Published online: 06 May 2020

\footnotetext{
References

1. Walsby AE. Structure and function of gas vacuoles. Bacteriol Rev. 1972;36(1): $1-32$.

2. Walsby AE. Gas Vesicles. Microbiol Rev. 1994;58(1):94-144.

3. Shapiro MG, Goodwill PW, Neogy A, Yin M, Foster FS, Schaffer DV, et al. Biogenic gas nanostructures as ultrasonic molecular reporters. Nat Nanotechnol. 2014;9(4):311-6.

4. Walsby AE. Buoyancy-providing role of gas vacuoles in an aerobic bacterium. Arch Microbiol. 1976;109(1-2):135-42.

5. Pfeifer F. Distribution, formation and regulation of gas vesicles. Nat Rev Microbiol. 2012;10(10):705-15.
} 
6. Lakshmanan A, Lu GJ, Farhadi A, Nety SP, Kunth M, Lee-Gosselin A, et al. Preparation of biogenic gas vesicle nanostructures for use as contrast agents for ultrasound and MRI. Nat Protoc. 2017;12(10):2050-80.

7. Kinsman R, Hayes PK. Genes encoding proteins homologous to halobacterial Gvps N, J, K, F \& L are located downstream of gvpC in the cyanobacterium Anabaena flos-aquae. DNA Seq. 1997;7(2):97-106.

8. Englert C, Pfeifer F. Analysis of gas vesicle gene expression in Haloferax mediterranei reveals that GvpA and GvpC are both gas vesicle structural proteins. J Biol Chem. 1993;268(13):9329-36.

9. Beard SJ, Hayes PK, Pfeifer F, Walsby AE. The sequence of the major gas vesicle protein, GvpA, influences the width and strength of halobacterial gas vesicles. FEMS Microbiol Lett. 2002;213(2):149-57.

10. Walsby AE, Hayes PK. Gas vesicle proteins. Biochem J. 1989;264(2):313-22.

11. Damerval T, Houmard J, Guglielmi G, Csiszar K. Tandeau de Marsac N. A developmentally regulated gvpABC operon is involved in the formation of gas vesicles in the cyanobacterium Calothrix 7601. Gene. 1987;54(1):83-92.

12. Mlouka A, Comte K, Castets AM, Bouchier C. Tandeau de Marsac N. The gas vesicle gene cluster from Microcystis aeruginosa and DNA rearrangements that lead to loss of cell buoyancy. J Bacteriol. 2004;186(8):2355-65.

13. Hayes PK, Powell RS. The gvpA/C cluster of Anabaena flos-aquae has multiple copies of a gene encoding GvpA. Arch Microbiol. 1995;164(1):50-7.

14. Walsby AE, Hayes PK. The minor cyanobacterial gas vesicle protein, Gvpc, is attached to the outer surface of the gas vesicle. J Gen Microbiol. 1988;134: 2647-57.

15. Hayes PK, Buchholz B, Walsby AE. Gas vesicles are strengthened by the outer-surface protein. GvpC Arch Microbiol. 1992;157(3):229-34.

16. Kinsman R, Walsby AE, Hayes PK. GvpCs with reduced numbers of repeating sequence elements bind to and strengthen cyanobacterial gas vesicles. Mol Microbiol. 1995;17(1):147-54.

17. Dunton PG, Mawby WJ, Shaw VA, Walsby AE. Analysis of tryptic digests indicates regions of GvpC that bind to gas vesicles of Anabaena flos-aquae. Microbiology. 2006;152(Pt 6):1661-9.

18. Xu BY, Dai YN, Zhou K, Liu YT, Sun Q, Ren YM, et al. Structure of the gas vesicle protein GvpF from the cyanobacterium Microcystis aeruginosa. Acta Crystallogr D Biol Crystallogr. 2014;70(Pt 11):3013-22.

19. Damerval T, Castets AM, Guglielmi G, Houmard J, Demarsac NT. Occurrence and distribution of gas vesicle genes among cyanobacteria. J Bacteriol. 1989:171(3):1445-52

20. Damerval T, Guglielmi G, Houmard J, De Marsac NT. Hormogonium differentiation in the cyanobacterium Calothrix: a photoregulated developmental process. Plant Cell. 1991;3(2):191-201.

21. Gonzalez A, Riley KW, Harwood TV, Zuniga EG, Risser DD. A tripartite, hierarchical sigma factor cascade promotes hormogonium development in the filamentous cyanobacterium Nostoc punctiforme. Msphere. 2019;4(3): e00231-19.

22. Kaneko T, Nakamura Y, Wolk CP, Kuritz T, Sasamoto S, Watanabe A, et al. Complete genomic sequence of the filamentous nitrogen-fixing cyanobacterium Anabaena sp. strain PCC 7120. DNA Res. 2001;8(5):205-13 27-53.

23. Dunton PG, Walsby AE. The diameter and critical collapse pressure of gas vesicles in Microcystis are correlated with GvpCs of different length. FEMS Microbiol Lett. 2005;247(1):37-43.

24. Li N, Cannon MC. Gas vesicle genes identified in Bacillus megaterium and functional expression in Escherichia coli. J Bacteriol. 1998;180(9):2450-8.

25. Holm L, Rosenstrom P. Dali server: conservation mapping in 3D. Nucleic Acids Res. 2010;38:W545-9.

26. El-Gebali S, Mistry J, Bateman A, Eddy SR, Luciani A, Potter SC, et al. The Pfam protein families database in 2019. Nucleic Acids Res. 2019;47(D1): D427-D32.

27. Erzberger JP, Berger JM. Evolutionary relationships and structural mechanisms of AAAt proteins. Annu Rev Biophys Biomol Struct. 2006;35: 93-114

28. Tashiro Y, Monson RE, Ramsay JP, Salmond GPC. Molecular genetic and physical analysis of gas vesicles in buoyant enterobacteria. Environ Microbiol. 2016;18(4):1264-76.

29. Gao H, Zhu T, Xu M, Wang S, Xu XD, Kong RQ. pH-dependent gas vesicle formation in Microcystis. FEBS Lett. 2016;590(18):3195-201.

30. Englert C, Horne M, Pfeifer F. Expression of the major gas vesicle protein gene in the halophilic archaebacterium Haloferax Mediterranei is modulated by salt. Mol Gen Genet. 1990;222(2-3):225-32.
31. Hechler T, Frech M, Pfeifer F. Glucose inhibits the formation of gas vesicles in Haloferax volcanii transformants. Environ Microbiol. 2008;10(1):20-30.

32. DasSarma P, Zamora RC, Muller JA, DasSarma S. Genome-wide responses of the model archaeon halobacterium sp strain NRC-1 to oxygen limitation. J Bacteriol. 2012;194(20):5530-7.

33. Ramsay JP, Williamson NR, Spring DR, Salmond GPC. A quorum-sensing molecule acts as a morphogen controlling gas vesicle organelle biogenesis and adaptive flotation in an enterobacterium. P Natl Acad Sci USA. 2011; 108(36):14932-7.

34. Pfeifer F. Haloarchaea and the formation of gas vesicles. Life (Basel). 2015; 5(1):385-402.

35. Pinto F, Pacheco CC, Ferreira D, Moradas-Ferreira P, Tamagnini P. Selection of suitable reference genes for RT-qPCR analyses in cyanobacteria. Plos One. 2012;7(4):e34983.

36. Livak KJ, Schmittgen TD. Analysis of relative gene expression data using real-time quantitative PCR and the 2 (-Delta Delta C(T)) method. Methods. 2001;25(4):402-8.

37. Vagin A, Teplyakov A. MOLREP: an automated program for molecular replacement. J Appl Crystallogr. 1997;30:1022-5.

38. Winn MD, Ballard CC, Cowtan KD, Dodson EJ, Emsley P, Evans PR, et al. Overview of the CCP4 suite and current developments. Acta Crystallogr D Biol Crystallogr. 2011;67:235-42.

39. Murshudov GN, Skubak P, Lebedev AA, Pannu NS, Steiner RA, Nicholls RA, et al. REFMAC5 for the refinement of macromolecular crystal structures. Acta Crystallogr D Biol Crystallogr. 2011;67:355-67.

40. Emsley P, Cowtan K. Coot: model-building tools for molecular graphics. Acta Crystallogr D Biol Crystallogr. 2004;60:2126-32.

41. Chen VB, Arendall WB, Headd JJ, Keedy DA, Immormino RM, Kapral GJ, et al. MolProbity: all-atom structure validation for macromolecular crystallography. Acta Crystallogr D Biol Crystallogr. 2010;66:12-21.

42. Scharschmidt BF, Keeffe EB, Blankenship NM, Ockner RK. Validation of a recording spectrophotometric method for measurement of membraneassociated mg- and NaK-ATPase activity. J Lab Clin Med. 1979;93(5):790-9.

\section{Publisher's Note}

Springer Nature remains neutral with regard to jurisdictional claims in published maps and institutional affiliations.

\section{Ready to submit your research? Choose BMC and benefit from:}

- fast, convenient online submission

- thorough peer review by experienced researchers in your field

- rapid publication on acceptance

- support for research data, including large and complex data types

- gold Open Access which fosters wider collaboration and increased citations

- maximum visibility for your research: over $100 \mathrm{M}$ website views per year

At $\mathrm{BMC}$, research is always in progress.

Learn more biomedcentral.com/submissions 